\title{
Strategi Pengembangan Industri Pengolahan Hasil Perikanan di Kecamatan Bulak Melalui Pendekatan Pengembangan Ekonomi Lokal
}

\author{
Nimas Asriningputri dan Ketut Dewi Martha Erli Handayeni \\ Departemen Perencanaan Wilayah dan Kota, Fakultas Arsitektur Desain dan Perencanaan \\ Institut Teknologi Sepuluh Nopember \\ e-mail: erli.martha@urplan.its.ac.id
}

\begin{abstract}
Abstrak-Kecamatan Bulak memiliki potensi sumber daya perikanan yang menjadi sektor basis dan lapangan usaha yang berkembang melalui subsektor perikanan. Namun potensi ini belum dapat dikembangkan secara optimal karena terdapat permasalahan dimana masyarakat pelaku usaha belum memanfaatkan keberadaan bangunan pusat pemasaran dan bangunan tempat pengolahan produk karena adanya perbedaan persepsi antar stakeholder yang disebabkan oleh pendekatan yang kurang melibatkan masyarakat dalam proses perencanaan hingga penyediaan infrastruktur pendukung pengolahan. Oleh karena itu, penelitian ini bertujuan merumuskan strategi prioritas pengembangan industri pengolahan hasil perikanan berbasis pengembangan ekonomi lokal di Kecamatan Bulak. Analisis yang digunakan dalam penelitian ini antara lain adalah statistik deskriptif, analisis konten, IFAS EFAS, dan analisis SWOT. Terdapat lima strategi prioritas pengembangan meningkatkan nilai jual produk melalui pemberian label pada kemasan produk kerupuk serta ikan asin dan pemberian kemasan vacuum pada produk ikan asap, menerapkan sistem penyortiran bahan baku dan pemasaran hasil produk secara terpusat di SIB, memanfaatkan penggunaan teknologi informasi dan komunikasi dalam pemasaran hasil produk olahan, memperluas jangkauan pemasaran melalui kegiatan pameran dan pengadaan kemitraan dengan toko oleh-oleh khas Surabaya, dan meningkatkan kerjasama pemerintah dan pelaku usaha terkait pengembangan kualitas tenaga kerja dalam pengolahan produk dan pengelolaan modal.
\end{abstract}

Kata Kunci-Pengembangan ekonomi lokal, industri pengolahan hasil perikanan, strategi pengembangan.

\section{PENDAHULUAN}

$\mathrm{K}$ ECAMATAN Bulak merupakan salah satu kecamatan di wilayah pesisir Kota Surabaya yang memiliki potensi perikanan. Kecamatan ini memiliki sektor basis dan potensi di bidang perikanan serta memiliki lapangan usaha yang berkembang melalui subsektor perikanan darat dan laut. Hal ini didukung dengan adanya industri berbasis rumah tangga yang terdapat di sekitar koridor Sukolilo-Kyai Tambak Deres dimana didominasi oleh industri pengolahan makanan yang bersumber dari hasil produktivitas nelayan di pesisir [1]. Jumlah industri pengolah hasil perikanan skala kecil dan menengah pada Kecamatan Bulak sebanyak 150 pengolah dan terdapat satu industri pengolahan bakso ikan, nugget ikan, dan abon ikan yang dikelola oleh Kelompok Srikandi[2].

Dalam pengembangan industri pengolahan hasil perikanan di Kecamatan Bulak terdapat peran beberapa stakeholder yang diGambarkan melalui program pelatihan pengolahan hasil perikanan dan program pelatihan pengolahan mutu pangan (diversifikasi pangan) dalam musyawarah perencanaan pembangunan. Melalui potensi dan upaya pengembangan industri pengolahan hasil perikanan yang telah ada ternyata masih belum berkontribusi secara optimal dalam peningkatan kesejahteraan penduduk. Hal ini diindikasikan dengan adanya permasalahan internal dari pelaku usaha dimana masih terdapat $12,44 \%$ penduduk miskin dari total keluarga di Kecamatan Bulak, jumlah modal per individu yang kecil, dan produk yang dihasilkan mudah ditiru oleh pihak lain [3].

Terdapat permasalahan eksternal berupa kurang optimalnya penggunaan sarana pendukung pengolahan seperti bangunan tempat pengolahan dan bangunan tempat pemasaran. Pelaku usaha enggan untuk menempati Sentra Ikan Bulak (SIB) sebagai bangunan pusat pemasaran walaupun sewa stan digratiskan, mereka lebih memilih berdagang di bahu jalan meskipun telah mendapat sosialisasi pemindahan menuju SIB. Selain itu, para pelaku usaha tetap memilih untuk melakukan pengasapan dan pengolahan di halaman rumah mereka sendiri-sendiri. Hal ini terjadi akibat adanya perbedaan persepsi antar stakeholder yang disebabkan oleh pendekatan yang kurang melibatkan masyarakat dan adanya permasalahan internal terkait pengelolaan sumber daya lokal yang kurang optimal[4]. Oleh karena itu, diperlukan kajian menggunakan pendekatan pengembangan ekonomi lokal (PEL) untuk meningkatkan kerjasama antar pemerintah, masyarakat, dan organisasi non pemerintah untuk menciptakan kondisi yang lebih baik dalam optimalisasi pengunaan sumber daya alam lokal dan sumber daya manusia lokal di Kecamatan Bulak. PEL menitikberatkan pada kelembagaan pembangunan sehingga pengembangan industri pengolahan hasil perikanan di Kecamatan Bulak akan optimal apabila dalam perumusan strateginya dapat mempertimbangkan faktor-faktor yang berkaitan dengan konsep PEL.

\section{METODE PENELITIAN}

\section{A. Pendekatan dan Jenis Penelitian}

Pendekatan yang digunakan dalam penelitian ini adalah pendekatan rasionalistik yang sifatnya komparasi dan verifikasi teori yang ada dengan data serta fakta empiris yang terjadi di lapangan [5]. Jenis penelitian yang digunakan adalah deskriptif yang bertujuan untuk mengGambarkan serta meringkaskan berbagai kondisi, situasi, dan fenomena realitas sosial yang ada di masyarakat yang menjadi objek penelitian [6]. 


\section{B. Variabel Penelitian}

Variabel penelitian berjumlah 20 variabel yang terbagi menjadi 6 indikator antara lain indikator sumber daya alam lokal, sumber daya manusia lokal, pemasaran, produksi, sarana prasarana, dan kelembagaan seperti pada Tabel 1 berikut.

Tabel 1.

Indikator dan Variabel Penelitian

\begin{tabular}{ll}
\hline \multicolumn{1}{c}{ Indikator } & \multicolumn{1}{c}{ Variabel } \\
\hline \hline Sumber daya alam lokal & Jumlah bahan baku \\
& Perolehan bahan baku \\
Sumber daya manusia & Jumlah tenaga kerja \\
lokal & Kualitas tenaga kerja \\
& Strategi Pemasaran \\
Pemasaran & Lingkup Pemasaran \\
Produksi & Jumlah produksi \\
& Inovasi produk \\
& Modal \\
& Teknologi produksi \\
& Akses jalan \\
Sarana dan prasarana & Jaringan listrik \\
& Jaringan air bersih \\
& Bangunan tempat pengolahan hasil \\
& perikanan olahan \\
& Bangunan tempat pemasaran hasil olah \\
& perikanan \\
& Pengolahan limbah \\
& Peran pemerintah \\
& Peran masyarakat \\
& Peran swasta \\
& Koperasi \\
\hline \hline
\end{tabular}

\section{Metode Sampling}

Metode sampling yang digunakan pada penelitian ini adalah probability sampling dengan jumlah populasi sebanyak 150 pelaku usaha olahan di Kecamatan Bulak, penentuan jumlah sampel menggunakan Rumus Slovin dengan tingkat error $10 \%$ sehingga sampel penelitian pada sasaran pertama berjumlah 60 pelaku usaha. Penentuan sampel penelitian pada sasaran kedua menggunakan analisis stakeholder sehingga diidentifikasi lima stakeholder yang terdiri atas dua dari pihak pemerintah yaitu Dinas Ketahanan Pangan dan Perikanan Kota Surabaya serta Kecamatan Bulak dan tiga dari pihak masyarakat yaitu pedagang kerupuk, pedagang ikan asap, dan pedagang ikan asin yang ada di Kecamatan Bulak.

\section{D.Teknik Analisis Data}

Dalam mengidentifikasi karakteristik industri pengolahan hasil perikanan di Kecamatan Bulak digunakan teknik analisis statistik deskriptif. Output yang dihasilkan berupa deskripsi terkait karakteristik industri pengolahan hasil perikanan di Kecamatan Bulak.

Dalam mengidentifikasi kekuatan, kelemahan, peluang, dan ancaman pengembangan industri pengolahan hasil perikanan di Kecamatan Bulak digunakan teknik analisis konten dengan bantuan software Nvivo 10. Output yang dihasilkan berupa faktor-faktor berpengaruh dalam pengembangan industri pengolahan hasil perikanan di Kecamatan Bulak.

Dalam menganalisis faktor internal dan eksternal yang memengaruhi pengembangan industri pengolahan hasil perikanan berdasarkan konsep PEL di Kecamatan Bulak digunakan IFAS EFAS sehingga output yang dihasilkan adalah faktor-faktor yang memengaruhi pengembangan industri pengolahan hasil perikanan.

Dalam merumuskan strategi prioritas pengembangan industri pengolahan hasil perikanan berbasis pengembangan ekonomi lokal di Kecamatan Bulak digunakan analisis
SWOT. Output yang dihasilkan berupa strategi prioritas pengembangan industri pengolahan hasil perikanan berbasis pengembangan ekonomi lokal di Kecamatan Bulak.

\section{HASIL DAN DISKUSI}

\section{A. Hasil dan Pembahasan}

\section{Identifikasi Karakteristik Industri Pengolahan Hasil Perikanan di Kecamatan Bulak}

Penggunaan analisis statistik deskriptif bertujuan untuk mengetahui karakteristik industri pengolahan hasil perikanan di Kecamatan Bulak. Responden pada sasaran ini adalah 60 pelaku usaha hasil olahan perikanan. Karakteristik yang teridientifikasi adalah sebagai berikut:

Jumlah Bahan Baku

Rata-rata penggunaan bahan baku pada industri kerupuk sebesar 202,15 kg/minggu, industri ikan asap sebesar 552 $\mathrm{kg} / \mathrm{minggu}$, dan industri ikan asin sebesar 15,54 kg/minggu.

Perolehan Bahan Baku

Perolehan bahan baku diperoleh dari dalam kecamatan melalui hasil tangkapan nelayan di Laut Kenjeran dengan persentase $70 \%$.

\section{Jumlah Tenaga Kerja}

Jumlah tenaga kerja didominasi sebanyak satu orang pada tiap industri dengan persentase 48,33\%

Kualitas Tenaga Kerja

Kualitas tenaga kerja didominasi oleh tamatan SD dengan persentase 48,94\%.

Strategi Pemasaran

Strategi pemasaran yang dominan diterapkan adalah pemasaran secara gabungan yaitu membuka toko, mengirim ke pengepul, dan menerima pesanan dengan persentase sebesar $60 \%$.

\section{Lingkup Pemasaran}

Lingkup pemasaran produk yang dominan adalah pemasaran di dalam dan luar kecamatan dengan persentase 53,33\%.

\section{Jumlah Produksi}

Rata-rata jumlah produksi pada industri kerupuk sebesar $172,38 \mathrm{~kg} /$ minggu, industri ikan asap sebesar 454,67 $\mathrm{kg} / \mathrm{minggu}$, dan industri ikan asin sebesar $111,71 \mathrm{~kg} / \mathrm{minggu}$. Inovasi Produk

Pada setiap jenis industri memiliki rata-rata jenis produk sebanyak 6-10 jenis dengan persentase 53,33\%.

Modal

Sumber modal yang paling dominan berasal dari modal pribadi dengan persentase 68,33\% dan jumlah modal paling dominan sebesar Rp 1.000.001-Rp 5.000.000 dengan persentase $50 \%$.

Teknologi produksi

Pada setiap jenis industri menggunakan teknologi produksi secara manual dalam proses pengolahannya dengan bantuan alat yang disesuaikan dengan kebutuhan produk olahan.

2. Analisis Kekuatan, Kelemahan, Peluang, dan Ancaman Pengembangan Industri Pengolahan Hasil Perikanan di Kecamatan Bulak

Pengunaan analisis konten dengan bantuan software Nvivo 10 bertujuan untuk membuat pemahaman terhadap teks mengenai konteksnya yang sifatnya valid dimana data yang akan dianalisis diperoleh melalui hasil wawancara dengan stakeholder kunci yang terdiri atas Dinas Ketahanan Pangan dan Pertanian Kota Surabaya, Kecamatan Bulak, pedagang hasil olahan kerupuk, pedagang hasil olahan ikan asin, dan pedagang hasil olahan ikan asap. 
Hasil identifikasi kekuatan, kelemahan, peluang, dan ancaman pengembangan industri pengolahan hasil perikanan adalah sebagai berikut:

\section{Jumlah Bahan Baku}

Jumlah bahan baku teridentifikasi sebagai faktor kekuatan (S1) melalui interpretasi hasil yaitu jumlah bahan baku yang melimpah dari dalam Kecamatan Bulak sehingga dapat mendukung kegiatan produksi dengan nilai coverage 0,48\%. Perolehan Bahan Baku

Perolehan bahan baku teridentifikasi sebagai faktor kekuatan (S2) melalui interpretasi hasil yaitu kemudahan dalam memperoleh bahan baku mampu mendukung kegiatan produksi setiap jenis industri pengolahan hasil perikanan dengan nilai coverage 0,29\%.

\section{Jumlah Tenaga Kerja}

Jumlah tenaga kerja teridentifikasi sebagai faktor kekuatan (S3) melalui interpretasi hasil yaitu Keberadaan tenaga kerja yang membantu efisiensi waktu dan tenaga para pelaku usaha dengan nilai coverage 0,50\%.

Kualitas Tenaga Kerja

Kualitas tenaga kerja teridentifikasi sebagai faktor kelemahan (W1) melalui interpretasi hasil yaitu kualitas tenaga kerja yang tergolong kurang baik dalam proses pengolahan perikanan yang sesuai standar dengan nilai coverage $0,33 \%$.

\section{Strategi Pemasaran}

Strategi pemasaran teridentifikasi sebagai faktor kekuatan (S4) melalui interpretasi hasil yaitu para pelaku usaha sudah memiliki inovasi dalam menerapkan strategi pemasaran dengan nilai coverage 0,435\%.

\section{Lingkup Pemasaran}

Lingkup pemasaran teridentifikasi sebagai faktor kekuatan (S5) melalui interpretasi hasil yaitu para pelaku usaha memiliki jangkauan pemasaran di dalam dan luar Kecamatan Bulak untuk mendukung pemasaran hasil produksi dengan nilai coverage 0,365\%.

\section{Jumlah Produksi}

Jumlah produksi teridentifikasi sebagai faktor kekuatan (S6) melalui interpretasi hasil yaitu hasil produksi yang mampu mencukupi dan menyesuaikan kebutuhan pasar dengan nilai coverage 0,27\%.

\section{Inovasi Produk}

Inovasi produk teridentifikasi sebagai faktor kekuatan (S7) melalui interpretasi hasil yaitu variasi produk yang mulai berkembang dan beragam untuk meningkatkan nilai jual produk serta meningkatkan minat konsumen dalam membeli produk olahan dengan nilai coverage 0,63\%.

Modal

Modal teridentifikasi sebagai faktor kelemahan (W2) melalui interpretasi hasil yaitu jumlah modal yang terg3olong rendah dan sering disalahgunakan diluar kepentingan usaha oleh para pelaku usaha dengan nilai coverage $0,22 \%$.

\section{Teknologi Produksi}

Teknologi produksi teridentifikasi sebagai faktor kekuatan (S8) melalui interpretasi hasil yaitu alat dan teknologi modern mulai berkembang dan teknik tradisional yang tetap dapat mendukung kegiatan produksi dengan nilai coverage 0,50\% Akses Jalan

Akses jalan teridentifikasi sebagai faktor peluang (O1) melalui interpretasi hasil yaitu akses jalan yang mendukung keberadaan industri dari segi kapasitas dan kelancaran dengan nilai coverage 0,27\%.

\section{Jaringan Listrik}

Jaringan listrik teridentifikasi sebagai faktor peluang (O2) melalui interpretasi hasil yaitu kondisi jaringan listrik yang memiliki penerangan dan kelancaran yang baik untuk mendukung kegiatan produksi dengan nilai coverage 0,25\%. Jaringan Air Bersih

Jaringan air bersih teridentifikasi sebagai faktor peluang (O3) melalui interpretasi hasil yaitu kondisi jaringan air bersih yang lancar dan selalu dilakukan perawatan secara rutin dengan nilai coverage $0,28 \%$.

\section{Bangunan Tempat Pengolahan Hasil Perikanan}

Bangunan tempat pengolahan hasil perikanan teridentifikasi sebagai faktor peluang (O4) melalui interpretasi hasil yaitu keberadaan bangunan tempat pengolahan hasil perikanan yang dilengkapi alat dan teknologi produksi yang lengkap serta memadai dengan nilai coverage 0,16\% dan sebagai faktor ancaman (T1) melalui interpretasi hasil yaitu keberadaan bangunan tempat pengolahan hasil perikanan yang tidak pernah atau jarang dimanfaatkan oleh para pelaku usaha dengan nilai coverage 0,36\%.

\section{Bangunan Tempat Pemasaran Hasil Olahan Perikanan}

Bangunan tempat pemasaran hasil olahan perikanan teridentifikasi sebagai faktor peluang (O5) melalui interpretasi hasil yaitu kondisi SIB yang dilengkapi fasilitas pendukung seperti keberadaan alat dan sarana prasarana yang memadai dengan nilai coverage 0,29\% dan teridentifikasi sebagai faktor ancaman (T2) melalui interpretasi hasil yaitu kondisi SIB yang sepi pengunjung dan tidak dimanfaatkan oleh sebagian pelaku usaha dengan nilai coverage $0,14 \%$.

Pengolahan Limbah

Pengolahan limbah teridentifikasi sebagai faktor ancaman (T3) melalui interpretasi hasil yaitu belum terdapat sistem pengolahan limbah secara khusus untuk pengolahan limbah industri yang memadai dengan nilai coverage $0,42 \%$.

Peran Pemerintah

Peran pemerintah teridentifikasi sebagai faktor peluang (O6) melalui interpretasi hasil yaitu adanya peran aktif dari pihak pemerintah berupa pemberian pelatihan dan bantuan alat dengan nilai coverage $0,53 \%$.

\section{Peran Masyarakat}

Peran masyarakat teridentifikasi sebagai faktor kelemahan (W3) melalui interpretasi hasil yaitu peran masyarakat pelaku usaha yang cenderung pasif dalam mengembangkan industri pengolahan hasil perikanan secara mandiri dengan nilai coverage $0,47 \%$.

Peran Swasta

Peran swasta teridentifikasi sebagai faktor ancaman (T4) melalui interpretasi hasil yaitu tidak adanya keberlanjutan kerja sama antar pihak swasta dengan para pelaku usaha hasil olahan perikanan dengan nilai coverage $0,22 \%$.

Koperasi

Koperasi teridentifikasi sebagai faktor kelemahan (W4) melalui interpretasi hasil yaitu belum adanya keberlanjutan koperasi sebagai lembaga peminjam modal untuk membantu para pelaku usaha dengan nilai coverage 0,34\%.

3. Analisis Faktor Internal dan Eksternal yang Memengaruhi Pengembangan Industri Pengolahan Hasil Perikanan Berdasarkan Konsep PEL di Kecamatan Bulak

Melalui metode IFAS EFAS dapat diketahui tingkat kepentingan (bobot) dan tingkat kinerja (rating) dari masingmasing faktor internal terkait kekuatan dan kelemahan serta 
faktor eksternal terkait peluang dan ancaman dalam pengembangan industri pengolahan hasil perikanan di Kecamatan Bulak. Hasil analisis terkait pemberian bobot dan rating melalui Tabel 2 faktor strategis internal (IFAS) dan Tabel 3 faktor strategis eksternal (EFAS) adalah sebagai berikut:

Tabel 2.

Faktor Strategis Internal

\begin{tabular}{|c|c|c|c|c|}
\hline Faktor Internal & Bobot & Bobot Relatif & Rating & Skor \\
\hline $\begin{array}{l}\text { Jumlah bahan baku yang } \\
\text { melimpah }\end{array}$ & 3,4 & 0,09 & 3,4 & 0,32 \\
\hline $\begin{array}{l}\text { Perolehan bahan baku yang } \\
\text { mudah }\end{array}$ & 3 & 0,08 & 3 & 0,25 \\
\hline $\begin{array}{l}\text { Terdapat inovasi dalam } \\
\text { penerapan strategi } \\
\text { pemasaran }\end{array}$ & 3,6 & 0,10 & 3,6 & 0,36 \\
\hline $\begin{array}{l}\text { Adanya jangkauan } \\
\text { pemasaran di dalam dan } \\
\text { luar Kecamatan Bulak }\end{array}$ & 2,6 & 0,07 & 3,6 & 0,26 \\
\hline $\begin{array}{l}\text { Hasil produksi mencukupi } \\
\text { kebutuhan pasar }\end{array}$ & 2,8 & 0,08 & 3,8 & 0,29 \\
\hline $\begin{array}{l}\text { Adanya variasi produk yang } \\
\text { beragam }\end{array}$ & 3,8 & 0,10 & 3,8 & 0,40 \\
\hline $\begin{array}{l}\text { Pengunaan alat serta } \\
\text { teknologi secara modern } \\
\text { dan tradisional }\end{array}$ & 3 & 0,08 & 2,8 & 0,23 \\
\hline Total Faktor Kekuatan & 24,4 & 0,67 & 27,2 & 2,30 \\
\hline $\begin{array}{l}\text { Kualitas tenaga kerja yang } \\
\text { kurang baik }\end{array}$ & 3,2 & 0,09 & 2,4 & 0,21 \\
\hline Penyalahgunaan modal & 2,2 & 0,06 & 1,8 & 0,11 \\
\hline $\begin{array}{l}\text { Peran masyarakat } \\
\text { cenderung pasif }\end{array}$ & 3,6 & 0,10 & 1,4 & 0,14 \\
\hline $\begin{array}{l}\text { Belum adanya } \\
\text { keberlanjutan koperasi }\end{array}$ & 2,8 & 0,08 & 2,6 & 0,20 \\
\hline Total Faktor Kelemahan & 11,8 & 0,33 & 8,2 & 0,46 \\
\hline
\end{tabular}

Tabel 3.

Faktor Strategis Eksternal

\begin{tabular}{lcccc}
\hline \multicolumn{1}{c}{ Faktor Internal } & Bobot & $\begin{array}{c}\text { Bobot } \\
\text { Relatif }\end{array}$ & Rating & Skor \\
\hline Akses jalan yang lancar & 2,2 & 0,07 & 3,6 & 0,26 \\
$\begin{array}{l}\text { Kondisi jaringan listrik yang baik } \\
\text { Kondisi jaringan air bersih yang }\end{array}$ & 2,8 & 0,09 & 4 & 0,36 \\
lancar & 3,8 & 0,12 & 3,8 & 0,47 \\
$\begin{array}{l}\text { Bangunan tempat pengolahan ikan } \\
\text { yang dilengkapi teknologi }\end{array}$ & 2 & 0,06 & 2,4 & 0,15 \\
$\begin{array}{l}\text { Bangunan tempat pemasaran hasil } \\
\text { perikanan yang dilengkapi sarana }\end{array}$ & 4,2 & 0,14 & 3,2 & 0,43 \\
prasarana & & & & \\
$\begin{array}{l}\text { Adanya peran aktif dari } \\
\text { pemerintah }\end{array}$ & 4 & 0,13 & 3,6 & 0,46 \\
$\begin{array}{l}\text { Total Faktor Peluang } \\
\text { Bangunan tempat pengolahan } \\
\text { perikanan yang tidak digunakan }\end{array}$ & 2,2 & 0,07 & 2,2 & 0,16 \\
$\begin{array}{l}\text { Kondisi tempat pemasaran hasil } \\
\text { olahan ikan yang sepi }\end{array}$ & 4,4 & 0,14 & 1,4 & 0,20 \\
$\begin{array}{l}\text { Belum terdapat sistem pengolahan } \\
\text { limbah }\end{array}$ & 2,8 & 0,09 & 2,2 & 0,20 \\
$\begin{array}{l}\text { Peran masyarakat cenderung pasif } \\
\text { Belum adanya keberlanjutan } \\
\text { koperasi }\end{array}$ & 3,6 & 0,10 & 1,4 & 0,14 \\
\begin{tabular}{l} 
Total Faktor Ancaman \\
\hline \hline
\end{tabular} & 2,8 & 0,08 & 2,6 & 0,20 \\
& 12 & 0,39 & 7,8 & 0,72 \\
\hline
\end{tabular}

4. Rumusan Strategi Prioritas Pengembangan Industri Pengolahan Hasil Perikanan Berbasis Pengembangan Ekonomi Lokal di Kecamatan Bulak

Pada Gambar 1 menunjukkan hasil penentuan posisi pada diagram cartesius SWOT diketahui melalui koordinat (x) dengan rumus skor kekuatan dikurangi kelemahan sedangkan koordinat (y) memiliki rumus skor peluang dikurangi ancaman dengan penjabaran sebagai berikut:

$$
\begin{aligned}
& \text { Koordinat }(\mathrm{x}):(2,30-0,46): 2=0,92 \\
& \text { Koordinat }(\mathrm{y}):(2,14-0,72): 2=0,71
\end{aligned}
$$

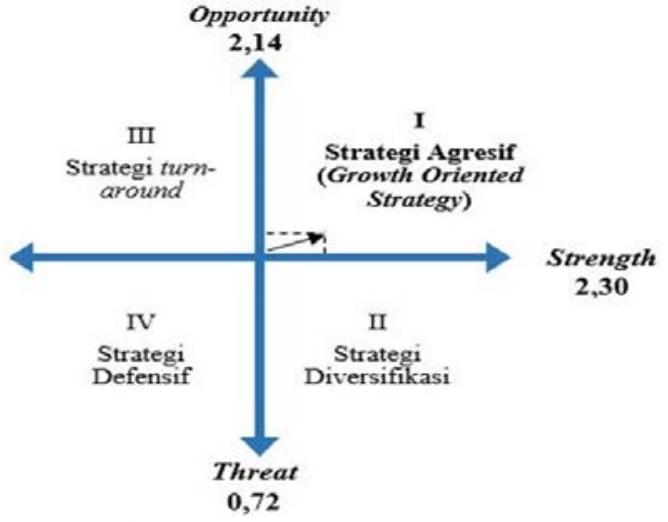

Gambar 1. Diagram Cartesius SWOT.

Berdasarkan posisi dalam diagram cartesius SWOT, strategi pengembangan industri pengolahan hasil perikanan di Kecamatan Bulak berada pada kuadran I dimana kondisi industri tersebut memiliki kekuatan untuk dapat memanfaatkan peluang yang ada. Strategi yang harus diterapkan dalam kondisi ini adalah mendukung kebijakan pertumbuhan yang agresif (growth oriented strategy) dengan menyilangkan faktor kekuatan dan peluang yang ada. Kemudian berdasarkan nilai bobot dari masing-masing faktor, diperoleh strategi prioritas pengembangan sebagai berikut:

a. Meningkatkan Nilai Jual Produk Melalui Pemberian Label Pada Kemasan Produk Kerupuk serta Ikan Asin dan Pemberian Kemasan Vacuum pada Produk Ikan Asap

Strategi ini dirumuskan dengan memperhatikan faktor kekuatan (internal) nomor 7, 4, dan 8 serta faktor peluang (eksternal) nomor 5 dan 6. Berdasarkan hasil pembobotan diketahui bahwa bobot kekuatan terkait variasi produk yang berkembang memiliki nilai sebesar 3,8, adanya inovasi dalam penerapan strategi pemasaran memiliki nilai sebesar 3,6, dan keberadaan alat teknologi yang memadai memiliki nilai sebesar 3 sehingga dapat memanfaatkan keberadaan faktor peluang melalui keberadaan bangunan tempat pemasaran (SIB) dengan bobot sebesar 4,2 dan adanya peran pemerintah dengan bobot sebesar 4. Strategi yang dirumuskan adalah meningkatkan nilai jual produk melalui pemberian label/stiker nama toko pada kemasan produk kerupuk dan ikan asin dan pemberian kemasan vacuum pada produk ikan asap. Peningkatan kualitas kemasan ini bertujuan agar produk olahan Kecamatan Bulak dapat dikenal oleh masyarakat dan meningkatkan daya tahan produk agar lebih awet

b. Menerapkan Sistem Penyortiran Bahan Baku dan Pemasaran Hasil Produk Secara Terpusat di Sentra Ikan Bulak

Strategi ini dirumuskan dengan memperhatikan faktor kekuatan (internal) nomor 1, 2, dan 8 serta faktor peluang (eksternal) nomor 5 dan 3. Berdasarkan hasil pembobotan diketahui bahwa bobot kekuatan terkait jumlah bahan baku 
yang melimpah memiliki nilai sebesar 3,4, kemudahan memperoleh bahan baku memiliki nilai sebesar 3, dan keberadaan alat teknologi yang memadai memiliki nilai sebesar 3 sehingga dapat memanfaatkan keberadaan faktor peluang melalui keberadaan bangunan tempat pemasaran (SIB) dengan bobot sebesar 4,2 dan prasarana pendukung berupa jaringan air bersih dengan bobot sebesar 3,8. Strategi yang dirumuskan adlah melalui sistem penyortiran bahan baku dan pemasaran hasil produk secara terpusat dimana bahan baku setelah diperoleh dari laut dapat langsung disalurkan ke bangunan pengolahan dan pemasaran untuk kemudian disortir sesuai dengan ukuran dan kualitasnya. Kegiatan pengolahan yang dapat dilakukan secara terpusat pada industri ikan asap dan ikan asin sedangkan pada industri kerupuk dapat dilaksanakan di rumah masing-masing. Pemasaran produk dapat dilakukan secara terpusat dengan memanfaatkan keberadaan SIB.

c. Memanfaatkan Penggunaan Teknologi Informasi dan Komunikasi dalam Pemasaran Hasil Produk Olahan

Strategi ini dirumuskan dengan memperhatikan faktor kekuatan (internal) nomor 8, 6, dan 5 serta faktor peluang (eksternal) nomor 2. Berdasarkan hasil pembobotan diketahui bahwa bobot kekuatan terkait keberadaan alat dan teknologi yang memadai memiliki nilai sebesar 3 , jumlah produk yang melimpah memiliki nilai sebesar 2,8, dan jangkauan pemasaran produk pada skala dalam serta luar kecamatan memiliki nilai sebesar 2,6 sehingga dapat memanfaatkan keberadaan faktor peluang melalui keberadaan prasarana berupa jaringan listrik yang memadai dalam mendukung kegiatan produksi maupun pemasaran produk dengan bobot sebesar 2,8. Strategi yang dirumuskan adalah memanfaatkan penggunaan teknologi informasi dan komunikasi dalam pemasaran hasil produk olahan sehingga produk olahan ini dapat dipasarkan secara tidak langsung. Strategi ini juga diharapkan mampu meningkatkan jangkauan pemasaran produk olahan agar lebih dikenal masyarakat luas

d. Memperluas Jangkauan Pemasaran Melalui Kegiatan Pameran dan Pengadaan Kerja sama dengan Toko OlehOleh Khas Surabaya

Strategi ini dirumuskan dengan memperhatikan faktor kekuatan (internal) nomor 4 dan 5 serta faktor peluang (eksternal) nomor 5 dan 6. Berdasarkan hasil pembobotan diketahui bahwa bobot kekuatan terkait adanya inovasi dalam penerapan strategi pemasaran memiliki nilai sebesar 3,6 dan adanya jangkauan pemasaran skala dalam serta luar kecamatan memiliki nilai sebesar 2,6 sehingga dapat memanfaatkan keberadaan faktor peluang melalui adanya keberadaan bangunan tempat pemasaran (SIB) dengan bobot sebesar 4,2 dan adanya peran aktif dari pihak pemerintah dalam mengembangkan industri dengan bobot sebesar 4 . Kemitraan antara pemerintah dan masyarakat pelaku usaha olahan perikanan di Kecamatan Bulak dalam mendukung pemasaran produk dapat ditingkatkan melalui kegiatan promosi dengan adanya pemasaran secara langsung berupa kegiatan pameran hasil produk yang rutin dilaksanakan di Kota Surabaya yang dapat diikuti oleh para pelaku usaha olahan perikanan secara bergilir. Selain itu, masyarakat pelaku usaha juga dapat menjalin kerja sama/kemitraan dengan toko oleh-oleh yang ada di Kota Surabaya sehingga produk ini dapat dipasarkan dan dikenalkan sebagai produk olahan hasil perikanan khas pesisir Kota Surabaya.

e. Meningkatkan Kerja sama Pemerintah dan Pelaku Usaha Terkait Pengembangan Kualitas Tenaga Kerja dalam Pengolahan Produk dan Pengelolaan Modal

Strategi ini dirumuskan dengan memperhatikan faktor kekuatan (internal) nomor 3 serta faktor peluang (eksternal) nomor 5, 6, dan 4. Berdasarkan hasil pembobotan diketahui bahwa bobot kekuatan terkait keberadaan tenaga dengan nilai sebesar 2,2 sehingga dapat memanfaatkan keberadaan faktor peluang melalui adanya keberadaan bangunan tempat pemasaran (SIB) dengan bobot sebesar 4,2, adanya peran aktif dari pihak pemerintah dalam mengembangkan industri dengan bobot sebesar 4, dan adanya bangunan tempat pengolahan hasil perikanan yang dilengkapi teknologi dengan bobot sebesar 2. Kurangnya keterampilan dan pengetahuan dalam mengolah produk dan mengelola modal, maka perlu diadakan pengadaan pelatihan keterampilan yang dilaksanakan dititikberatkan pada pengolahan produk menggunakan alat dan teknologi yang memadai yang telah tersedia pada bangunan tempat pengolahan perikanan dan bangunan tempat pemasaran dengan memperhatikan standar kebersihan dan kesehatan produksi. Pemerintah juga dapat bekerja sama dengan para pelaku usaha yang memiliki pengalaman dalam mengelola modal untuk memberikan pelatihan kepada para pelaku usaha yang lain melalui pelatihan terkait pengelolaan modal agar dapat digunakan sesuai kebutuhan usaha.

\section{KESIMPULAN}

Strategi pengembangan industri pengolahan hasil perikanan di Kecamatan Bulak berada pada kuadran I dalam diagram cartesius SWOT dimana industri tersebut memiliki kekuatan untuk dapat memanfaatkan peluang yang ada. Berdasarkan pertimbangan nilai bobot dan karakteristik industri pada faktor kekuatan dan peluang yang disilangkan, maka dapat diperoleh lima strategi prioritas pengembangan yaitu meningkatkan nilai jual produk melalui pemberian label pada kemasan produk kerupuk serta ikan asin dan pemberian kemasan vacuum pada produk ikan asap, menerapkan sistem penyortiran bahan baku dan pemasaran hasil produk secara terpusat di Sentra Ikan Bulak, memanfaatkan penggunaan teknologi informasi dan komunikasi dalam pemasaran hasil produk olahan, meningkatkan kerja sama pemerintah dan pelaku usaha terkait pengembangan kualitas tenaga kerja dalam pengolahan produk dan pengelolaan modal, dan memperluas jangkauan pemasaran melalui kegiatan pameran dan pengadaan kerja sama dengan toko oleh-oleh khas Surabaya.

\section{DAFTAR PUSTAKA}

[1] “Rencana Tata Ruang Wilayah Kota Surabaya Tahun 2010-2030.”

[2] B. Perikanan and D. Kelautan, "Profil Perikanan Kota Surabaya 2012."

[3] E. W. Safitri, "Pengembangan dan Pelatihan Konsep One Village One Product Berbasis Ekonomi Lokal untuk Peningkatan Kesejahteraan Masyarakat Pesisir Pantai Kenjeran di Kota Surabaya,” 2016.

[4] N. SARI and EKA, "Partisipasi Pedagang dalam Pengembangan Sentra Ikan Bulak di Kecamatan Bulak Kota Surabaya,” Publika, vol. 5, no. 1, 2017.

[5] Rimadewi Supriharjo, Dian Rahmawati, and Karina Pradinie, "Diktat Metlit.”.

[6] W.Gulo, "Metode Penelitian." 